\title{
The Role of Phospholipase A in Gallstone Formation
}

\author{
SATINDRA K. GOSWAMI, PII.D., AND ChARLES F. FREY, M.D.
}

CHOLESTEROL IS THE MAIN COMPONENT of human gallstones. It is held in solution in bile by mixed micelles of lecithin and bile salts [1]. Presence of both lecithin and bile salts are $\mathbf{e}_{i}$ sential for the solubilization of cholesterol in bile [2]. Normal human gallbladder bile is almost saturated with cholesterol [3]. Therefore, a small change in lecithin concentration might disturb the micellar solubility of cholesterol. Bacterial degradation of lecithin lowers the solubility of cholesterol in bile [4]. The conversion of lecithin to lysolecithin and fatty acids may be catalyzed by the enzyme phospholipase A. This enzyme is a normal component of pancreatic secretion, and the presence of this enzyme has been demonstrated in duodenal contents of man [5]. It has also been demonstrated in vitro that if the fatty acids liberated by the action of phospholipase $\mathrm{A}$ are removed from the micellar mixture, lysolccithin alone would not be able to hold the cholesterol in solution and hence the latter will be precipitated [6]. The absorption of fatty acids, liberated by the hydrolysis of lecithin in vitro, by the gallbladder has been demonstrated with the guinea pig gallbladder [7]. The presence of phospholipase A activity of human gallbladder bile from patients with gallstones and chronic cholecystitis has not been determined.

From the Department of Surgery, Wayne County General Hospital, Eloise, Michigan 48132 and University of Michigan Medical Center, Ann Arbor, Michigan 48104.

Submitted for publication March 10, 1973.

\section{MATERIALS AND METHODS}

Bile samples from 40 patients with gallstones were collected by puncture of the gallbladder during operation. An aliquot was immediately cultured in media amenable to growth of aerobic and anaerobic bacteria and the rest was frozen and stored at $-16^{\circ}$ for further analysis.

Pure lecithin, lysolecithin, and glycine (Sigma Chemical Co., St. Louis, MO), boric acid, potassium hydroxide, sodium deoxycholate, chloroform, and methanol (Matheson, Coleman and Bell, Norwood, $\mathrm{OH})$ were used in the chemical determinations.

The incubation system consisted of a buffer diluent, substrate, and enzyme source [5]. The diluent was a mixture of $0.1 M$ glycine in $0.05 \mathrm{M}$ borate buffer, $\mathrm{pH}$ 8.45. This was prepared as follows: 0.6184 $\mathrm{g}$ of boric acid was dissolved in $100 \mathrm{ml}$ water and $1.502 \mathrm{~g}$ of glycine was added to it and dissolved. Potassium hydroxide solution was then added until the $\mathrm{pH}$ of 8.45 at $200 \mathrm{ml}$ was reached.

The substrate contained $25 \mathrm{mg}$ lecithin and $20 \mathrm{mg}$ sodium deoxycholate in $4 \mathrm{ml}$ glycine borate buffer. Three tubes were takcn for cach spccimen of gallbladdcr bilc tested. The first two tubes contained $1 \mathrm{ml}$ of the enzyme source (gallbladder bile diluted 1:25 with the glycerine borate buffer) mixed with $1 \mathrm{ml}$ of buffer. The third tube served as the control and contained $2 \mathrm{ml}$ of buffer. All the tubes were preheated at $55^{\circ} \mathrm{C}$ for $30 \mathrm{~min}$ in a water bath and then the incubation was continued by adding 4 $\mathrm{ml}$ of substrate in the first and the third 
tubes and $4 \mathrm{ml}$ of buffer in the second tube at the same temperature for $1 \mathrm{hr}$.

Phospholipids were extracted from $1 \mathrm{ml}$ of the incubation mixture with $19 \mathrm{ml}$ chloroform-methanol 2:1 (VIV). The choloroform phase was then evaporated to dryness under nitrogen at $40^{\circ} \mathrm{C}$. The lipid was redissolved immediately in $0.2 \mathrm{ml}$ of chloroform; $0.04 \mathrm{ml}$ was spotted in duplicate on a $20 \times 20-\mathrm{cm}$ precoated thin-layer plate silica gel F-254 of $0.25-\mathrm{mm}$ thickness (E. Merck, A.G., Darmstadt, Germany, distributed by Brinkmann Instruments, Inc., Westbury, NY) to form a band 2 $\mathrm{cm}$ wide. Chromatograms were developed by means of chloroform-methanol-water (65:25:4 vol). Lecithin and lysolecithin were identified by running standards and spraying the plate with copper-molybdenum spray reagent [8].

\section{RESULTS AND DISCUSSION}

Samples of human gallbladder bile from 40 patients were cultured for aerobic and anaerobic bacteria. Samples of gallbladder bile from 30 patients had no bacterial growth. Four of these patients had acute cholecystitis and 26 chronic cholecystitis. Bacterial growth was noted in cultures of bile samples from 10 patients four of whom had acute cholecystitis and six chronic cholecystitis. None of the tubes of the samples tested showed the presence of lysolecithin in the chromatogram which proves the absence of phospholipase $A$ in gallbladder bile of gallstone patients at the time of operation in patients with acute and chronic cholecystitis with and without bacterial growth.

Our inability to demonstrate phospho- lipase $\mathrm{A}$ in the bile of 40 consecutive patients with cholecystitis leads us to believe that it is unlikely that phospholipase $\mathrm{A}$ has a significant role in gallstone formation in man.

\section{SUMMARY}

Gallbladder bile of patients with gallstones having acute or chronic cholecystitis were examined for phospholipase $\mathrm{A}$ activity. None of the specimens tested showed any sign of this enzyme. It is unlikely that the mechanism of gallstone formation in patients with acute and chronic cholecystitis involves phospholipase A.

\section{REFERENCES}

1. Hofmann, A. F. Clinical implications of physicochemical studies on bile salts. Gastroenterology 48:484, 1965.

2. Small, D. M. The formation of gallstones. Advan. Intern. Med. 16:243, 1970.

3. Small, D. M. Gallstones. N. Engl. J. Med. 279:588, 1968.

4. Yoshimuta, S. Factors affecting on solubility of cholesterol in bile. Fukuoka Acta Med. 51:510, 1961.

5. Vogel, W. C., and Ziere, L. A lecithinase A in duodenal contents of man. J. Clin. Invest. $39: 1295,1960$.

6. Neiderhiser, D. H., and Roth, H. P. Effect of phospholipase $A$ on cholesterol solubilization by lecithin in a bile salt solution. Gastroenterology 58:26, 1970.

7. Neiderhiser, D. H., Pineda, H' M., Hejduk, L. J., and Roth, H. P.: Absorption of colic acid by the guinea pig gallbladder. J. Lab. Clin. Med. 77:985, 1971.

8. Goswami, S. K., and Frey, C. F. Spray detection of phospholipids on thin-layer chromatograms. J. Lipid Res. 12:509, 1971.

9. Ziere, L., and Vogel, W. C. Measurement of lecithinase $\mathrm{A}$ in serum and other body fluids. J. Lab. Clin. Med. 57:586, 1961. 